\title{
Effectiveness of Growth Regulators Application of Table Variety Moldovany Yield and Quality in Postharvest Storage During Fungicide Load Reduction
}

\author{
S. Levchenko \\ All-Russian National Research Institute of Viticulture and \\ Winemaking "Magarach" \\ Yalta, Russia \\ svelevchenko@rambler.ru

\section{Vasylyk} \\ All-Russian National Research Institute of Viticulture and \\ Winemaking "Magarach" \\ Yalta, Russia \\ kalimera@inbox.ru
}

\author{
A. Batukaev \\ Chechen State University \\ Grozny, Russia \\ batukaev_abuzar@mail.ru
}

\author{
D. Belash \\ All-Russian National Research Institute of Viticulture and \\ Winemaking "Magarach" \\ Yalta, Russia \\ dima-244@mail.ru
}

\begin{abstract}
The influence of growth regulators was studied based on yield and quality of table variety 'Moldova' and by the dynamics of post-harvest storage. The use of growth regulators during $30 \%$ fungicide load reduction enhances the weight of grapes and berries harvest by $11-14 \%$, increases the mass concentration of sugar in juice and improves the sensory evaluation to 8.2-8.8 points. The yield of standard products in the experiment variants' was increased by $3.6-7.7 \%$ compared to the control. The impact of growth regulators on sensory evaluation of table grapes and the value of the natural losses of a bunch mass during storage period are described. The results show that the use of growth regulators significantly improves the quality of 'Moldova' table variety. The study demonstrated that after 90 days of storage the natural cluster weight loss index was lower in the grapes that had been treated with the preparation as compared to control. Under treatments with different growth regulators, the sensory evaluation of Moldova variety rises up to 8.4-8.7 points. In addition, it is shown that these indicators were preserved over the long-term storage of grapes.
\end{abstract}

Keywords - bunch weight, growth regulator, natural loss, postharvest quality, sensory evaluation, sugarconcentration, storage period,table grape

\section{INTRODUCTION}

Viticulture is a promising sector of the agro-industrial complex of the Republic of Crimea. The natural conditions of Crimea are highly diverse, thus, the natural and climatic profile of a particular region determines the focus of viticulture and varietal composition of the vineyards (Levchenko S. 2015, Likhovskoi V., 2016). It is known that the competent use of fertilizers and growth regulators in a vineyard is one of the main factors that increase the yield and quality of grapes. Taking into account the need to reduce the cost of production, priority shall be given to plant nutritional regime adjustment by growth regulators (Elfving, D.C., 2010; Jamwal, M. et al., 2010; Beibulatov M., Boyko V., 2014; Borisenko M, 2007; Vilchinsky V, et al., 2001; Volynkin V. et al., 2015; Levchenko S. et al., 2016; Levchenko S., 2016). At present, there is a wide range of new generation fertilizers and growth regulators, thus, making the study of their influence on grape productivity and quality of the harvest very relevant. "Albit" is one of such promising preparations. It is a natural biopolymer poly-beta-hydroxybutyric acid from soil bacteria Bacillus megaterium. The mechanism of "Albit" action is based on stimulating the natural protective reactions of a plant. Due to its anti-stress action, the use of "Albit" preparation allows preserving a significant share of the yield (up to $68 \%$ ) (Zlotnikov et al., 2009). In the last decade, "Albit" has been widely used on winter wheat, barley, sugar beet, rape and other crops. Interesting results were also obtained from "Albit" application on grape culture. In the experiments conducted by the Institute "Magarach", the preparation helped improve the organoleptic properties and strengthened the varietal aromas of the berries of table grapes, increased the 
mass of the bunch and of the berries, maximized harvest by $14 \%$ and sugar content of the juice by $7 \%$ (Zlotnikov and Modonkaeva, 2016). "Mival-Agro" is another environmentally safe preparation with a wide range of biological effects, adaptogenic and antioxidant properties. It intensifies the vital processes in plants, increases their resistance to unfavorable growing conditions, such as, rapid temperature changes, winter and spring frosts, heat and drought, or, on the contrary, soil waterlogging and insufficient sum of active temperatures (Levchenko S. et al., 2016). The purpose of this work is to study the effect of "Albit" and "Mival-Agro" preparations on the quality and productivity of table grapes in the conditions of the Republic of Crimea as well as their influence on the quality of grapes during storage.

\section{METHODS AND MATERIALS}

The studies were carried out at Morskoye Branch of PJSC "Massandra" during the 2015 growing season, in the vineyards under Moldova variety applying the experiment scheme presented in Table 1 . The sample size was 25 pieces in 3-way repetition for each variant of the experiment (Dospehkov B.A., 1985). The work is based on "Methodological recommendations on agro-technical research in the viticulture of Ukraine" (Avidzba A. et al., 2004); "Methodological recommendations for the evaluation of table grapes" (Mondokaeva A. et al., 2012). The total polyphenol content (TPC) was determined by the Folin-Ciocalteu method.

TABLE I. EXPERIMENTAL DESIGN “THE EFFECT OF PREPARATION “ALBIT” AND “MIVAL-AGRO” ON PRODUCTIVITY AND QUALITY OF GRAPES"

\begin{tabular}{|c|c|c|c|}
\hline $\begin{array}{l}\text { Preparations } \\
\text { growth } \\
\text { regulators }\end{array}$ & Treatment periods & $\begin{array}{c}\text { Preparation } \\
\text { dosage }\end{array}$ & $\begin{array}{r}\text { Fungicide } \\
\text { quantity }\end{array}$ \\
\hline \multicolumn{4}{|c|}{ 'Moldova', (furrow irrigation) } \\
\hline \multirow[t]{4}{*}{ "Albit" } & $\begin{array}{l}\text { Growth of shoots and } \\
\text { blossom clusters (the } 3^{\text {d }}- \\
5^{\text {th }} \text { leaf phase) }\end{array}$ & $200 \mathrm{ml} / \mathrm{ha}$ & - \\
\hline & Pre-bloom & $200 \mathrm{ml} / \mathrm{ha}$ & $70 \%$ \\
\hline & $\begin{array}{l}\text { Onset of berry growth } \\
\text { and formation }\end{array}$ & $200 \mathrm{ml} / \mathrm{ha}$ & $70 \%$ \\
\hline & $\begin{array}{l}\text { Veraison (a month } \\
\text { before harvesting) }\end{array}$ & $200 \mathrm{ml} / \mathrm{ha}$ & $70 \%$ \\
\hline & \multicolumn{3}{|l|}{ 'Moldova '(no irrigation) } \\
\hline \multirow[t]{4}{*}{ "Albit" } & $\begin{array}{l}\text { Growth of shoots and } \\
\text { blossom clusters (the } 3^{\text {d }}- \\
5^{\text {th }} \text { leaf phase) }\end{array}$ & $200 \mathrm{ml} / \mathrm{ha}$ & - \\
\hline & Pre-bloom & $200 \mathrm{ml} / \mathrm{ha}$ & $70 \%$ \\
\hline & $\begin{array}{l}\text { Onset of berry growth } \\
\text { and formation }\end{array}$ & $200 \mathrm{ml} / \mathrm{ha}$ & $70 \%$ \\
\hline & $\begin{array}{l}\text { Veraison (a month } \\
\text { before harvesting) }\end{array}$ & $200 \mathrm{ml} / \mathrm{ha}$ & $70 \%$ \\
\hline \multicolumn{4}{|c|}{ 'Moldova '(no irrigation) } \\
\hline \multirow[t]{4}{*}{ "Mival-Agro" } & $\begin{array}{l}\text { Growth of shoots and } \\
\text { blossom clusters (the } 3^{\text {d }}- \\
5^{\text {th }} \text { leaf phase) }\end{array}$ & $15 \mathrm{~g} / \mathrm{ha}$ & - \\
\hline & Pre-bloom & $15 \mathrm{~g} / \mathrm{ha}$ & $70 \%$ \\
\hline & $\begin{array}{l}\text { Onset of berry growth } \\
\text { and formation }\end{array}$ & $15 \mathrm{~g} / \mathrm{ha}$ & $70 \%$ \\
\hline & $\begin{array}{l}\text { Veraison (a month } \\
\text { before harvesting) }\end{array}$ & $15 \mathrm{~g} / \mathrm{ha}$ & $70 \%$ \\
\hline
\end{tabular}

*-Fertilizing schedule adopted at the farm - 10 chemical treatments per season, no foliar treatments

\section{RESULTS}

Analysis of the data obtained has shown that 'Moldova' was most responsive to "Albit" preparation. Average bunch weight on control bushes constituted $258 \mathrm{~g}$, while under test conditions this indicator increased by $82.9 \%$. Thus, the average yield per bush under test conditions exceeded control by $10.7 \%$. Accordingly, the estimated yields in the vineyards where "Albit" was applied increased up to $21.8 \mathrm{t} / \mathrm{ha}$, which allowed obtaining an up to 2.1 ton per hectare increase in the yield. Application of "Albit" preparation improved the quality of the grapes, while standard product output increased by $7 \%$ as compared to control (table 2).

TABLE II. YIELD AND STANDARD PRODUCT OUTPUT

\begin{tabular}{|c|c|c|c|c|c|}
\hline $\begin{array}{c}\text { Test } \\
\text { variations }\end{array}$ & $\begin{array}{c}\text { Average } \\
\text { Bunch } \\
\text { weight, } \\
\text { g. }\end{array}$ & $\begin{array}{l}\text { Yield in } \\
\text { kg. }\end{array}$ & $\begin{array}{c}\text { Yield in } \\
\text { t/ha }\end{array}$ & $\begin{array}{c}\text { Yield } \\
\text { surplus, } \\
\text { t. }\end{array}$ & $\begin{array}{c}\text { Standard } \\
\text { Product } \\
\text { output, } \\
\%\end{array}$ \\
\hline \multicolumn{6}{|c|}{ "Albit" (no irrigation) } \\
\hline Control & 258 & 5.91 & 19.70 & & 89.8 \\
\hline Test & 481 & 6.54 & 21.80 & +2.1 & 96.1 \\
\hline $\begin{array}{c}\text { Student's t- } \\
\text { test }\end{array}$ & 0.004 & 0.001 & 0.033 & & \\
\hline \multicolumn{6}{|c|}{ "Albit" (furrow irrigation) } \\
\hline Control & 337 & 5.15 & 17.16 & & 94.6 \\
\hline Test & 406 & 5.89 & 19.63 & +1.56 & 95.1 \\
\hline $\begin{array}{c}\text { Student's t- } \\
\text { test }\end{array}$ & 0.003 & 0.001 & 0.051 & & \\
\hline \multicolumn{6}{|c|}{ "Mival-Agro" } \\
\hline Control & 258 & 5.91 & 19.70 & & 89.8 \\
\hline Test & 595 & 6.47 & 21.56 & +1.86 & 93.7 \\
\hline $\begin{array}{c}\text { Student's t- } \\
\text { test }\end{array}$ & 0.003 & 0.001 & 0.022 & & \\
\hline
\end{tabular}

Application of "Albit" preparation combined with irrigations ( 3 furrow irrigations during vegetation period) had a positive impact on the yield and quality increase of the product. Thus, the average bunch weight in the test variant made $406 \mathrm{~g}$, which exceeds control by $20.5 \%$, the average yield per bush made $5.89 \mathrm{~kg}(+14.4 \%)$. The estimated yield increased by $11.5 \%$ on the plot where "Albit" was used. Yield surplus due to "Albit" application made 2.4 tonnes. Standard product output in the test variant equaled that of the control $(+0.5 \%)$. However, the parameters under investigation turned out to be below those observed in the variant without irrigation. Therefore, the data obtained by us as well as the data obtained by A.E. Mondokaeva (Zlotnikov. Mondokaeva et al., 2016) suggest that under stress conditions (no irrigation) the "Albit" impact on the yield and quality of the grapes increases, as it is a stress inhibiting preparation.

Plant bioregulators had a positive effect on sugar content in the test samples. Sugar level in grape berries raised by $6.7-$ $9.8 \%$ depending on test variation. Application of "MivalAgro" preparation had a significant impact on concentration of sugars, titrated acids and total phenolic compounds in the berries of 'Moldova' variety. "Mival-Agro" application allowed obtaining grape yield with higher total sugars and insignificant alteration of the titrated acidity (table 3 ). 
TABLE III. THE IMPACT OF GROWTH REGULATORS ON THE CHEMICAL AND BIO-CHEMICAL INDICATORS OF TABLE GRAPES

\begin{tabular}{|l|c|c|c|c|}
\hline $\begin{array}{c}\text { Test } \\
\text { variations }\end{array}$ & $\begin{array}{c}\text { Sugarcontent, } \\
\text { ( }\end{array}$ & $\begin{array}{c}\text { Total } \\
\text { acidity } \\
\text { (g L }\end{array}$ & $\begin{array}{c}\text { Gluco- } \\
\text { acidometric } \\
\text { index }\end{array}$ & $\begin{array}{c}\text { Total phenolic } \\
\text { compounds, } \\
\text { (g L } \mathbf{~}^{-1)}\end{array}$ \\
\hline Control & 16.4 & 6.8 & 2.4 & 545.6 \\
\hline "Albit" & 17.5 & 6.0 & 2.9 & 553.0 \\
\hline $\begin{array}{l}\text { "Mival- } \\
\text { Agro" }\end{array}$ & 18.0 & 7.5 & 2.4 & 642.0 \\
\hline $\begin{array}{l}\text { Fisher LSD } \\
\text { test-, p<0,05 }\end{array}$ & 0.13 & 0.002 & 0.012 & 9.542 \\
\hline
\end{tabular}

It was established that application of the preparations under investigation improved commercial quality characteristics of the product (table 4); however, "MivalAgro" influenced quality characteristics to a greater extent. 'Moldova' variety control sample cultivated on arid soils was evaluated at 7.8 points. The bunch had the typical external appearance, was small-sized; the berries were uneven in size. The taste was varietal, simple and harmonious. The skins were somewhat crude with fleshy juicy pulp. Grape samples from the bushes treated with "Mival-Agro" preparation were evaluated at the level of 8.7 points. The bunch was big, fine, and quite outstanding for 'Moldova' variety grapes. The berries were even in shape and bigger that in the control sample, with heavy pruina coating; the skin was also solid, palpable.

TABLE IV. ORGANOLEPTIC EVALUATION OF 'MOLDOVA' VARIETY

\begin{tabular}{|c|c|c|c|c|}
\hline Test & $\begin{array}{c}\text { Bunch and } \\
\text { berry external } \\
\text { appearance (0.1- } \\
\mathbf{2 . 0} \text { points) }\end{array}$ & $\begin{array}{c}\text { Taste } \\
\text { and } \\
\text { aroma } \\
\mathbf{( 1 . 0 - 5 . 0} \\
\text { points) }\end{array}$ & $\begin{array}{c}\text { Skin and pulp } \\
\text { characteristics } \\
\mathbf{( 1 . 0 - 3 . 0} \text { points) }\end{array}$ & $\begin{array}{c}\text { Overall } \\
\text { score, by } \\
\text { points }\end{array}$ \\
\hline Control & 1.5 & 4.1 & 2.2 & 7.8 \\
\hline "Albit" & 1.7 & 4.2 & 2.3 & 8.2 \\
\hline $\begin{array}{c}\text { "Mival- } \\
\text { Agro" }\end{array}$ & 1.9 & 4.5 & 2.3 & 8.7 \\
\hline $\begin{array}{c}\text { Fisher } \\
\text { LSD } \\
\text { test-, } \\
\text { p }<0.05\end{array}$ & 0.11 & 0.23 & 0.04 & 0.01 \\
\hline
\end{tabular}

Grape samples of 'Moldova' variety ("Albit") from furrow irrigation plot were estimated at 8.2 points. The skin and pulp characteristics in the control were evaluated at the level of 2.3 points due to the easily broken skin that was barely perceptible when eating. In the test variant the exterior appearance of the bunch and the berries was estimated higher (1.7 points) as compared to the control (1.5 points). Test samples were characterized by a more harmonious, soft, and uncharacteristic for 'Moldova' variety berry taste -4.3 points as compared to 3.6 points in control and 4.1 points in the sample grown on arid soil. The pulp was fleshy, juicy, and pleasant on the palate -2.5 points. Thus, higher degustation points received by the testing samples were due to harmonious combination of the standard indicators.

Table 5 shows the economic effect obtained due to treatment with the preparations. Since foliar fertilizing results in reduced fungicidal load, the total cost in the foliar fertilizing variant is lower due to cost savings on fungicides. Thus, $30 \%$ fungicidal load reduction minimized expenditure by 27.6 roubles per hectare.

TABLE V. ECONOMIC EFFECTS FROM APPLICATION OF "ALBIT" AND "MIVAL-AGRO" PREPARATIONS COMBINED WITH REDUCED FUNGICIDAL LOAD

\begin{tabular}{|c|c|c|c|c|}
\hline \multirow{2}{*}{ Cultivar } & \multirow{2}{*}{$\begin{array}{c}\text { Fungicidal } \\
\text { load } \\
\text { reduction, \% }\end{array}$} & \multicolumn{2}{|c|}{$\begin{array}{c}\text { Expenditures per } 1 \\
\text { ha, RUB }\end{array}$} & \multirow{2}{*}{$\begin{array}{c}\text { Cost savings on } \\
\text { fungicides, in } \\
\text { thousands of } \\
\text { roubles }\end{array}$} \\
\hline & & control & test & \\
\hline Albit & 30 & 95824.3 & 68256.6 & 27.6 \\
\hline $\begin{array}{l}\text { Mival } \\
\text { Agro }\end{array}$ & 30 & 95824.3 & 61906.0 & 33.9 \\
\hline
\end{tabular}

Application of "Albit" preparation combined with reduced fungicidal load allowed yield increase by $2.1 \mathrm{t} / \mathrm{ha}$. Net profit from the yield increase made 142.4 thousand roubles from 1 ha. Net profit from the yield increase in the case of "MivalAgro" made 272.6 thousand roubles from 1 ha (table 6)

Overall, positive changes in economic efficiency indicators following foliar fertilizing improved profitability of Moldova grapes up to $121.2 \%$.

Plant bioregulators could improve yield, quality and postharvest life (Greene, D.W., 2010). Within the framework of the studies, estimates were made of the impact from foliar treatments with growth stimulants on commercial quality indicators of table grapes and their alteration during postharvest storage (table 7).

The study found that growth stimulants application had a positive effect on the organoleptic characteristics of the table grapes studied (Table 7).

TABLE VI. ECONOMIC EFFECTS FROM APPLICATION OF THE PREPARATIONS

\begin{tabular}{|c|c|c|c|c|c|c|c|}
\hline \multirow{2}{*}{ Cultivar } & \multicolumn{2}{|c|}{$\begin{array}{l}\text { Yield, } \\
\text { t/ha }\end{array}$} & \multirow{2}{*}{$\begin{array}{l}\text { Surplus, } \\
\text { t/ha }\end{array}$} & \multirow{2}{*}{$\begin{array}{l}\text { Sale price of } 1 \mathrm{~kg}, \\
\text { roubles }\end{array}$} & \multirow{2}{*}{$\begin{array}{l}\text { Profit from yield surplus from } 1 \text { ha, in thousands } \\
\text { of roubles }\end{array}$} & \multirow{2}{*}{$\begin{array}{l}\text { From } \quad \text { yield } \\
\text { surplus }\end{array}$} & \multirow{2}{*}{$\begin{array}{l}\text { Net } \\
\text { profit }\end{array}$} \\
\hline & control & test & & & & & \\
\hline Albit & 19.70 & 21.80 & 2.10 & 67.80 & 142.4 & 169.9 & 142.4 \\
\hline $\begin{array}{l}\text { Mival- } \\
\text { Agro }\end{array}$ & 17.73 & 21.75 & 2.04 & 67.80 & 272.6 & 234.5 & 272.6 \\
\hline
\end{tabular}


TABLE VII. THE IMPACT OF “ALBIT” PREPARATION ON QUALITY INDICATORS IN THE DYNAMICS OF THE POST-HARVEST STORAGE

\begin{tabular}{|c|c|c|c|c|c|}
\hline \multicolumn{2}{|c|}{ Test variants } & $\begin{array}{c}\text { Beginning } \\
\text { of storage }\end{array}$ & $\begin{array}{c}\mathbf{3 0} \\
\text { days }\end{array}$ & $\begin{array}{c}\mathbf{9 0} \\
\text { days }\end{array}$ & $\begin{array}{c}\mathbf{1 5 0} \\
\text { days }\end{array}$ \\
\hline $\begin{array}{c}\text { Sugar content, } \\
\left({ }^{0} \text { Brix }\right)\end{array}$ & Control & 16.4 & 18.0 & 15.6 & 17.3 \\
\cline { 2 - 6 } & Test & 17.5 & 19.4 & 15.4 & 20.7 \\
\hline \multirow{2}{*}{$\begin{array}{c}\text { Total } \\
\text { acidity } \\
\left(\text { g L }^{-1}\right)\end{array}$} & Control & 6.8 & 6.0 & 4.1 & 8.0 \\
\cline { 2 - 6 } & Test & 6.0 & 6.0 & 3.9 & 5.9 \\
\hline $\begin{array}{c}\text { Average bunch } \\
\text { weight, g }\end{array}$ & Control & 477.5 & 453 & 445 & 434.5 \\
\cline { 2 - 6 } & Test & 608.5 & 585 & 568 & 554 \\
\hline $\begin{array}{c}\text { Natural mass } \\
\text { wastage, } \%\end{array}$ & Control & - & 5.13 & 7.04 & 9.01 \\
\cline { 2 - 6 } & Test & - & 3.86 & 6.66 & 8.96 \\
\hline $\begin{array}{c}\text { Tasting assessment, } \\
\text { points }\end{array}$ & Control & 7.4 & 7.2 & 7.2 & 7.2 \\
\cline { 2 - 6 } & Test & 8.4 & 8.7 & 8.4 & 7.6 \\
\hline
\end{tabular}

The conducted research allowed us to study the change dynamics in the total sugars and titrated acids during longterm storage of table grapes. Notice was taken of the varietal specificity of the change in the total sugars. The change in the total sugars during long-term storage depends on two competing processes. The first one is the relative increase in the sugar content due to evaporation of free water by grapeberry tissues, while the absolute content of sugars remains unchanged. The mechanism of the second process is as follows: since grape berries are enzyme substrates of the transferase class capable of synthesizing polysaccharides, storage decreases the glucose and fructose concentrations, which are the main monosaccharides of the grape berry.

Cultivars suitable for long-term storage are characterized by lower enzyme activity (Levchenko, 2016). Moldova grapes change this indicator in a different way. Thus, after 30 days of storage there is a relative increase in the mass concentration of sugars associated with water evaporation processes. A decrease in the sugar content is registered after 90 days of storage, as the influence of enzymatic processes increases. After 150 days of storage, berries partially dry, berry tissues lose turgor, which leads to a relative increase in the mass concentration of sugars.

During storage, the weight of grapes decreases due to natural loss. The natural loss of the grapes' weight depends on the intensity of metabolic processes. The continuity of metabolic processes occurring in grapes during storage requires energy, the main source of which is respiratory gas exchange and oxidation processes that occur with participation of oxidoreductases, which include peroxidase and polyphenol oxidase. Therefore, the natural mass loss during storage is dependent on respiration intensity and oxidative enzymes' activity. Taking into account those processes, the enzyme activity can serve as one of the main criteria for selecting cultivars suitable for long-term storage.

Within the existing table grapes storage technology, the main losses are incurred by producers due to natural weight loss. Studies demonstrated that storage losses are largely due to the natural weight loss. The microbiological damage and berry sloughing contribution to the total grape weight loss is minimal.
The maximum weight loss due to natural wastage was registered in the control variants during the first 30 days of storage. It was established that application of growth regulators reduced the natural weight loss value of table grapes during the 90 days of storage.

\section{CONCLUSION}

In light of the foregoing experimental data, it can be concluded that application of "Albit" preparation increased 'Moldova' variety productivity during cultivation, both in conditions of drip irrigation and on arid soils. The use of "Albit" preparation increased the yield of 'Moldova' variety by 10.7 - 14.4\%, improved commercial quality (by 7\%) and transportable properties of Moldova grapes cultivated on arid soils, increased total sugars, improving the taste of fresh grapes, which affected the tasting assessment results (8.0-8.2 points in test samples). We registered an improvement in the organoleptic properties of Moldova grapes after "Mival-Agro" application (taste panel score made 8.7 points), which was due to an accord in standard indices resulting from the use of the preparation. "Mival-Agro" application decreases activity of peroxidase and polyphenol oxidase along with respiratory gas exchange intensity, which allows longer-term preservation of biologically active substances' reserve, and reduces the natural loss of the mass of the grapes. Experimental treatment schedule of Moldova grapes with "Mival-Agro" preparation provides for a net income of 240.6 thousand rubles per hectare, while treatment with "Albit" preparation results in net income of 142.4 thousand rubles/ha. The obtained data provide rationale for the system of protective measures and organo-mineral fertilizing involving "Albit TPC" and "MivalAgro" preparations in agrotechnologies.

\section{References}

[1] S.V. Levchenko, "Evaluation of table grape forms of independent selection as to their agrobiological and economic characteristics", The aspects of agrarian and industrial complex development of the region, vol. 3 (23), pp. 43-47.

[2] V. Likhovskoi, V. Volynkin, M. Borisenko, N. Oleinikov, I. Vasylyk, L. Troshin, Agrobiological specificity of selection forms - analogues of local varieties of the Crimean grapes, 2016.

[3] "Magarach", Viticulture and Winemaking, vol. 2, pp. 3-5.

[4] D.C. Elfving, "Plant bioregulators in the deciduous fruit tree nursery", ActaHortic, vol. 884, 2010, pp. 159-166. DOI 10.17660/ActaHortic.2010.884.18https://doi.org/10.17660/ActaHortic.2 010.884 .18

[5] M. Jamwal, S. Sharma, and S. Sahay, "Use of plant bio-regulators", In: The Pear: Production, Post-Harvest Management and Protection R.M. Sharma, S.N. Pandey and V. Pandey Eds. India: IBDC Publishers, 2010, pp.365-379

[6] M.R. Beibulatov, V.A. Boyko, "Impact assessment of foliar fertilizing on productivity of table grapes", "Magarach".Viticulture and Winemaking, vol. 2, 2014, pp.11-14

[7] M.N. Borisenko, "Optimization of methods for watering a grape cattery","Magarach". Viticulture and Winemaking, 2007, pp. 9-12.

[8] V. Vilchinsky, M. Borisenko, V. Dzemakulov, "Application of new generation growth regulators in viticulture", Viticulture and Winemaking, vol. 32, 2001, pp. 37-39. 
[9] S.V. Levchenko, I.A. Vasylyk, V.A. Boyko, "Effectiveness of "Albit" preparation on Moldova variety grapes in the conditions of the Republic of Crimea", Viticulture and Winemaking, vol. 5, 2016, pp.36-39.

[10] S.V. Levchenko, "A comparative assessment of preparations used in foliar fertilizing as to their effect on the yield and quality of grapes placed in storage", "Magarach".Viticulture and Winemaking, vol. 1, 2016, pp.17-19.

[11] S.V. Levchenko, E.V. Ostroukhova, I.A. Vasylyk, V.A. Boyko, N.Yu. Lutkova, "Impact assessment of foliar fertilizing with "Albit" and "Mival-Agro" preparations on the yield of grapes and quality of table wine materials", Scientific works of the Federal State Budget Scientific Organization "North Caucasian Regional Research Institute of Horticulture and Viticulture" of the Russian Academy of Agricultural Sciences, vol. 11, 2016, pp. 99-104.

[12] B. Dospehkov, Methods of field experiment. Moscow: Agropromizdat, 1985 , p. 544.
[13] Avidzba A., et el, Methodological recommendations on agro-technical research in the viticulture of Ukraine". Yalta, 2004, p. 264

[14] Mondokaeva A., et el, Methodological recommendations for the evaluation of table grapes, Yalta, 2012, p. 68.

[15] K. A. Zlotnikov, V. T. Alyokhin, A. D. Andrianov, et al, Biopreparation "Albit" for improvement of crop and plant protection: experiments, recommendations, application results. Moscow, Agrus, 2009, p. 248.

[16] A.K. Zlotnikov, K.M. Zlotnikov, A.E. Modonkaeva, et al, The impact of "Albit" on the quality of agricultural crops.Plants protection and quarantine, vol. 2, 2016, pp. 41-44.

[17] D.W. Greene, "The development and use of plant bioregulators in tree fruit production", ActaHortic, vol. 884, 2010, pp. 31-40. DOI: 10.17660/ActaHortic.2010.884.1https://doi.org/10.17660/ActaHortic.20 10.884 .1 